\title{
Correction to: The impact of long dry periods on the aboveground biomass in a tropical forest: 20 years of monitoring
}

Milton Serpa de Meira Junior * (0), José Roberto Rodrigues Pinto, Natália Oliveira Ramos, Eder Pereira Miguel, Ricardo de Oliveira Gaspar and Oliver L. Phillips

\section{Correction to: Carbon Balance Manage (2020) 50:12} https://doi.org/10.1186/s13021-020-00147-2

Following publication of the original article [1], the authors noticed an error in the article title which was published incorrectly. The correct title is given below: "The impact of long dry periods on the aboveground biomass in a tropical forest: 20 years of monitoring".

The article title has been updated above and the original article [1] has been corrected.

\section{Reference}

1. Meira Junior MS, Pinto JRR, Ramos NO, Miguel EP, Oliveira Gaspar R, Phillips OL. The impact of long dry periods on the aboveground biomass in a tropical forest: 20 years of monitoring. Carbon Balance Manage. 2020;50:12. https://doi.org/10.1186/s13021-020-00147-2.

\section{Publisher's Note}

Springer Nature remains neutral with regard to jurisdictional claims in published maps and institutional affiliations.

Received: 25 June 2020 Accepted: 25 June 2020

Published online: 10 July 2020 is not included in the article's Creative Commons licence and your intended use is not permitted by statutory regulation or exceeds the permitted use, you will need to obtain permission directly from the copyright holder. To view a copy of this licence, visit http://creativeco mmons.org/licenses/by/4.0/. The Creative Commons Public Domain Dedication waiver (http://creativecommons.org/publicdomain/ zero/1.0/) applies to the data made available in this article, unless otherwise stated in a credit line to the data. 